\title{
Perbedaan Kadar Kolesterol Total pada Anak yang Terinfeksi dan Tidak Terinfeksi Intestinal Geohelminth
}

\author{
M. Randi Sakti Pratama ${ }^{1}$, Nurhayati ${ }^{2}$, Siti Nurhajjah ${ }^{3}$
}

\begin{abstract}
Abstrak
Intestinal geohelminth masih banyak ditemui di negara berkembang terutama Indonesia. Infeksi cacing ini dapat menganggu pencernaan, penyerapan, dan metabolisme makanan, salah satunya adalah terhadap kadar kolesterol. Tujuan: Mengetahui perbedaan kadar kolesterol total pada anak yang terinfeksi dan tidak terinfeksi intestinal geohelminth. Metode: Jenis penelitian ini adalah studi analitik dengan jumlah sampel 46 orang siswa SDN 06 Pasir Jambak Kota Padang (23 orang terinfeksi dan 23 orang tidak terinfeksi). Penelitian dilakukan sejak bulan Mei sampai Desember 2016. Pemeriksaan jenis cacing dari tinja dilakukan di bagian Parasitologi FK Unand dengan menggunakan teknik Kato-Katz, sedangkan kadar kolesterol menggunakan pengukur kadar kolesterol digital. Analisis data menggunakan uji t-test. Hasil: Pada 23 orang yang terinfeksi intestinal geohelminth, infeksi paling banyak disebabkan oleh Trichuris trichiura sebanyak 15 siswa (65,21 \%), Ascaris lumbricoides sebanyak 11 siswa (47,82 \%), campuran sebanyak 3 siswa (13,04\%). Rata-rata kadar kolesterol total pada anak yang terinfeksi intestinal geohelminth yaitu $161,17 \pm 33,66 \mathrm{mg} / \mathrm{dl}$, sedangkan tidak terinfeksi yaitu 190,91 $\pm 42,20 \mathrm{mg} / \mathrm{dl}$. Secara statistik didapatkan perbedaan yang bermakna $(p=0,01)$. Simpulan: Terdapat perbedaan kadar kolesterol total pada anak yang terinfeksi dan tidak terinfeksi intestinal geohelminth. Anak yang terinfeksi memiliki kadar kolesterol total yang lebih rendah daripada anak yang tidak terinfeksi.
\end{abstract}

Kata kunci: Intestinal geohelminth, kolesterol total, siswa SD

\section{Abstract}

Intestinal geohelminth which is still prevalent in developing countries, particularly Indonesia. This worm infections can interrupt digestive process, absorption process, and metabolism of food, one of it is the total cholesterol level. Objectives: To determined the differences in total cholesterol levels in children that were infected and uninfected by intestinal geohelminth. Methods: This study was an analytic with number of samples were 46 students of SDN 06 Jambak Pasir Padang City (23 infected and 23 uninfected people). This study was conducted since May until December 2016. The examination of worm types from the feces samples taken place in Parasitology Laboratory of FK Unand using the Kato-Katz technique, whereas the cholesterol levels were measured using a digital cholesterol levels measurement. Data were analyzed using t-test. Results: From 23 people infected with intestinal geohelminth, most infections are caused by Trichuris trichiura on 15 students (65.21\%), Ascaris lumbricoides on 11 students (47.82\%), a combination of all on 3 students (13.04\%). The average total cholesterol levels in children infected with intestinal geohelminth is $161.17 \pm 33.66 \mathrm{mg} / \mathrm{dl}$, while on the uninfected is $190.91 \pm 42.20 \mathrm{mg} / \mathrm{dl}$. Statistically significant differences found $(p=0.01)$. Conclusion: There are differences in the total cholesterol levels in infected and uninfected children by intestinal geohelminth. The children that were infected have lower total cholesterol levels than the children that were uninfected.

Keywords: Intestinal geohelminths, total cholesterol, elementary students

Affiliasi penulis: 1. Prodi Pendidikan Dokter, Fakultas Kedokteran, Universitas Andalas, Padang, Indonesia. 2. Bagian Parasitologi, Fakultas Kedokteran, Universitas Andalas, Padang, Indonesia. 3.
Bagian Anatomi, Fakultas Kedokteran, Universitas Andalas, Padang, Indonesia.

Korespondensi: M. Randi Sakti Pratama, Email:

muhammadrandisaktipratama@gmail.com Telp: 082281439144 


\section{PENDAHULUAN}

Infeksi cacing yang ditularkan melalui tanah atau dikenal dengan intestinal geohelminth masih banyak ditemui di Indonesia. Spesies intestinal geohelminth yang menginfeksi manusia antara lain cacing gelang (Ascaris lumbricoides), cacing cambuk (Trichuris trichiura), cacing tambang (Necator americanus dan Ancylostoma duodenale), dan Strongiloides stercoralis. ${ }^{1}$

Infeksi intestinal geohelminth terjadi pada lebih dari 2 milyar orang penduduk di dunia. Perkiraan jumlah penduduk di dunia yang terinfeksi $A$. lumbricoides berkisar lebih dari 1 miliar jiwa, $T$. trichiura berkisar 795 juta jiwa dan cacing tambang berkisar 740 juta jiwa. ${ }^{2}$ Infeksi cacing di Indonesia masih tinggi. Tingginya prevalensi ini didukung oleh iklim tropis dan kelembaban udara yang tinggi di Indonesia, karena merupakan lingkungan yang sangat baik untuk perkembangan cacing. ${ }^{3}$

Hasil pemeriksaan tinja yang dilakukan pada delapan provinsi di Indonesia tahun 2008 menunjukkan bahwa Sumatera Barat memiliki angka prevalensi kecacingan yang tinggi, yakni 10,1\%. Angka kejadian pada 22 Puskesmas di Kota Padang menunjukkan 283 kasus berasal dari Puskesmas Lubuk Buaya, diikuti oleh Puskesmas Aia Dingin sebanyak 233 kasus dan Puskesmas Anak air sebanyak 134 kasus. $^{5}$

Infeksi intestinal geohelminth dapat menganggu pencernaan, penyerapan, dan metabolisme makanan. Hal ini dapat menimbulkan kekurangan gizi berupa kalori dan protein, serta kehilangan darah yang berakibat menurunnya daya tahan tubuh. Kekurangan gizi dapat menimbulkan gangguan tumbuh kembang anak terutama pada infeksi berat. ${ }^{6}$

Penelitian yang dilakukan di Inggris menunjukkan bahwa, tikus yang terinfeksi cacing memiliki risiko $50 \%$ lebih rendah mengalami aterosklerosis dibandingkan yang tidak terinfeksi. ${ }^{7}$ Ini disebabkan karena pada tikus yang terinfeksi cacing memiliki kadar kolesterol total serum $40 \%$ lebih rendah dibandingkan yang tidak terinfeksi cacing. Kadar kolesterol total serum dipengaruhi oleh jumlah telur dan jumlah cacing yang menginfeksi. ${ }^{8}$
Penelitian yang dilakukan di Nigeria menunjukkan bahwa anak yang terinfeksi cacing memiliki kadar kolesterol total yang lebih rendah dibandingkan yang tidak terinfeksi cacing. ${ }^{9}$ Rendahnya kadar kolesterol tersebut berdampak terhadap sintesis kortikosteroid, hormon seks, asam empedu, dan vitamin $\mathrm{D}$ didalam tubuh. ${ }^{10}$

Sekolah Dasar Negeri (SDN) 06 Pasir Jambak Kecamatan Koto Tangah Kota Padang merupakan sekolah yang berjarak sekitar 50 meter dari pantai dan terletak di permukiman masyarakat yang kumuh, serta kebiasaan masyarakat buang air besar di sepanjang pantai tersebut sehingga menjadikan tempat ini sangat cocok untuk penyebaran infeksi intestinal geoheminth.

Berdasarkan hasil penelitian diatas, diduga terdapat peranan infeksi cacing terhadap kadar kolesterol total baik pada hewan tikus maupun anakanak. Namun, penelitian belum pernah dilakukan di Sekolah Dasar Negeri (SDN) 06 Pasir Jambak Kota Padang. Oleh karena itu, perlu dilakukan penelitian tentang perbedaan kadar kolesterol total pada anak yang terinfeksi dan tidak terinfeksi intestinal geohelminth.

\section{METODE}

Jenis penelitian ini adalah analitik dengan pendekatan Case Control Study dilakukan di SDN 06 Pasir Jambak Kota Padang pada bulan Mei sampai dengan Desember 2016. Jumlah sampel sebanyak 46 orang. Penentuan status infeksi dilakukan dengan pemeriksaan tinja dengan metode Kato-Katz sedangkan kadar kolesterol ditentukan dengan alat ukur kolesterol digital.

\section{HASIL}

\section{Data penelitian}

Penelitian ini dilakukan pada siswa kelas 1-6 SDN 06 Pasir Jambak Kecamatan Koto Tangah Kota Padang. Total sampel dalam penelitian ini adalah 46 orang yang dibagi menjadi dua kelompok, yaitu 23 orang siswa terinfeksi dan 23 orang siswa yang tidak terinfeksi intestinal geohelminth. Karakteristik dari responden dapat dilihat pada Tabel 1. 
Tabel 1. Karakteristik subjek penelitian

\begin{tabular}{lcc}
\hline \multirow{2}{*}{ Karakteristik } & \multicolumn{2}{c}{ Kelompok } \\
\cline { 2 - 3 } & Terinfeksi (\%) & Tidak terinfeksi \\
& $\mathrm{n}=23$ & $(\%)$ \\
& & $\mathrm{n}=23$ \\
\hline Jenis kelamin & & $12(52,17)$ \\
$\quad$ Laki-laki & $9(39,13)$ & $11(47,83)$ \\
$\quad$ Perempuan & $14(60,87)$ & \\
Usia & & $14(60,87)$ \\
$<10$ tahun & $11(47,83)$ & $9(39,13)$ \\
$\geq 10$ tahun & $12(52,17)$ & $9,22 \pm 1,88$ \\
$\quad$ Rata-rata & $9,43 \pm 1,95$ & \\
IMT & & $16,95 \pm 0,87$ \\
Rata-rata & $17,15 \pm 0,96$ & $16,1-18,8$ \\
$\quad$ Rentang & $16,3-21,1$ &
\end{tabular}

Tabel 1 didapatkan bahwa infeksi intestinal geohelminth tertinggi ditemukan pada siswa dengan jenis kelamin perempuan $(60,87 \%)$, sedangkan pada kelompok tidak terinfeksi jumlah responden laki-laki lebih banyak (52,17\%). Usia pada kelompok terinfeksi ditemukan paling banyak pada usia $\geq 10$ tahun yaitu sebanyak 12 orang (52,17 \%), sedangkan pada kelompok tidak terinfeksi ditemukan paling banyak pada usia < 10 tahun (60,87 \%). Rata-rata usia pada kedua kelompok tidak terlalu berbeda yaitu kelompok terinfeksi 9,43 dan kelompok tidak terinfeksi 9,22. Rata-rata Indeks Massa Tubuh (IMT) pada kelompok terinfeksi yaitu 17,15 , sedangkan pada kelompok tidak terinfeksi yaitu 16,95.

Distribusi infeksi intestinal geohelminth berdasarkan spesies dan intensitas infeksi dapat dilihat pada Tabel 2.

Tabel 2. Distribusi infeksi intestinal geohelminth berdasarkan spesies

\begin{tabular}{lr}
\hline \multicolumn{1}{c}{ Variabel } & $\begin{array}{r}\text { Frekuensi (\%) } \\
\mathbf{n = 2 3}\end{array}$ \\
\hline Jenis Cacing & $11(47,82)$ \\
Ascaris lumbricoides & $15(65,21)$ \\
Trichuris trichiura & $0(0)$ \\
Cacing Tambang & $3(13,04)$ \\
Mix Ascaris lumbricoides & \\
dan Trichuris trichiura & \\
Intensitas infeksi & $23(100)$ \\
Ringan & $0(0)$ \\
Sedang & $0(0)$ \\
Berat & \\
\hline
\end{tabular}

Tabel 2 menunjukkan bahwa dari 23 orang yang terinfeksi, jenis infeksi intestinal geohelminth yang paling banyak menginfeksi pada siswa adalah Trichuris trichiura $(65,21 \%)$ dan ditemukan infeksi campuran Ascaris lumbricoides dan Trichuris trichiura berjumlah 3 orang (13,04\%). Sementara infeksi yang disebabkan oleh cacing tambang dan infeksi campuran lainnya tidak ditemukan. Intensitas infeksi yang terjadi pada seluruh siswa bersifat ringan.

Perbedaan kadar kolesterol total pada anak yang terinfeksi dan tidak terinfeksi intestinal geohelminth dapat dilihat pada Tabel 3.

Tabel 3. Perbedaan kadar kolesterol total pada anak yang terinfeksi dan tidak terinfeksi intestinal geohelminth

\begin{tabular}{|c|c|c|c|}
\hline \multirow[t]{2}{*}{ Variabel } & \multicolumn{2}{|c|}{ Kelompok } & \multirow[b]{2}{*}{$\begin{array}{c}\mathrm{P} \\
(t-t e s t)\end{array}$} \\
\hline & $\begin{array}{c}\text { Terinfeksi } \\
(\mathrm{n}=23)\end{array}$ & $\begin{array}{c}\text { Tidak } \\
\text { terinfeksi } \\
(n=23)\end{array}$ & \\
\hline $\begin{array}{l}\text { Kadar } \\
\text { kolesterol } \\
(\mathrm{mg} / \mathrm{dl})\end{array}$ & & & \\
\hline Rata-rata & $161,17 \pm$ & $190,91 \pm$ & 0,011 \\
\hline SD & 33,661 & 42,196 & \\
\hline Median & 149,00 & 185,00 & \\
\hline Rentang & $104-232$ & $134-271$ & \\
\hline
\end{tabular}

Tabel 3 didapatkan hasil perbedaan kadar kolesterol total pada anak yang terinfeksi dan tidak terinfeksi intestinal geohelminth. Anak yang terinfeksi intestinal geohelminth memiliki rata-rata kadar kolesterol total yang lebih rendah yaitu 161,17 \pm 33,66 $\mathrm{mg} / \mathrm{dl}$ dibandingkan rata-rata kadar kolesterol total anak yang tidak terinfeksi yaitu 190,91 \pm 42,20 mg/dl. Sehingga berdasarkan uji statistik kedua kelompok tersebut menunjukkan terdapat perbedaan kadar kolesterol yang bermakna antara anak yang terinfeksi dan tidak terinfeksi intestinal geohelminth pada siswa SDN 06 Pasir Jambak Kecamatan Koto Tangah Kota Padang dengan nilai $p 0,011(p<0,05)$.

\section{PEMBAHASAN}

Hasil penelitian ini menunjukkan bahwa terdapat sedikit perbedaan jumlah antara anak perempuan dan anak laki-laki yang terinfeksi intestinal geohelminth. Anak perempuan lebih banyak terinfeksi 
daripada anak laki-laki. Hasil penelitian ini sama dengan penelitian yang dilakukan oleh Rahman (2015) yang juga menemukan infeksi intestinal geohelminth lebih tinggi pada anak perempuan daripada anak lakilaki. ${ }^{11}$ Penelitian yang dilakukan oleh Handayani et al (2015) juga menunjukkan bahwa infeksi intestinal geohelminth lebih banyak terjadi pada anak perempuan daripada anak laki-laki. ${ }^{12}$ Hasil penelitian ini berbeda dengan penelitian yang dilakukan Uneke et al (2007) yang menunjukkan bahwa infeksi intestinal geohelminth lebih banyak terjadi pada anak laki-laki daripada anak perempuan. ${ }^{13}$ Saat ini belum ada data yang menyatakan bahwa jenis kelamin mempengaruhi kejadian infeksi intestinal geohelminth, kemungkinan terdapat faktor yang mempengaruhi seseorang terinfeksi cacing ini yaitu kebiasaan, sanitasi, lingkungan, pendidikan, sosial, dan ekonomi. ${ }^{14}$

Berdasarkan kelompok usia, infeksi intestinal geohelminth tertinggi terjadi pada usia $\geq 10$ tahun tahun. Hasil penelitian ini sama dengan penelitian yang dilakukan oleh Samudar yang juga menemukan infeksi intestinal geohelminth tertinggi pada kelompok umur yang sama. ${ }^{6}$ Hasil penelitian yang dilakukan oleh Ginting juga menunjukkan infeksi intestinal geohelminth tertinggi pada kelompok anak dengan umur yang lebih tua yaitu 9-11 tahun. $^{15} \mathrm{Hal}$ ini berhubungan dengan tingginya aktifitas bermain dan mobilitas anak yang lebih tua sehingga resiko tertular cacing lebih besar. Sementara pada anak yang lebih muda lebih mendapatkan pengawasan dari orang tua tentang masalah higienenya.

Spesies cacing yang menginfeksi didapatkan infeksi terbanyak disebabkan oleh Trichuris trichiura sebanyak 15 orang $(65,21 \%)$, Tidak ditemukan adanya siswa yang terinfeksi cacing tambang, disebabkan karena daerah penelitian bukan daerah perkebunan dan pertambangan yang merupakan rantai penyebaran cacing tambang, selain itu juga disebabkan karena waktu dilakukan pemeriksaan tinja yang lebih dari 1 hari sehingga telur cacing tambang berubah menjadi larva infektif. Hasil penelitian ini sama dengan penelitian yang dilakukan oleh Handayani et al (2015) yang menunjukkan bahwa infeksi terbanyak juga disebabkan oleh Trichuris trichiura sebanyak 3 orang $(4,1 \%) .{ }^{12}$ Penelitian lain yang dilakukan oleh Elmi et al juga didapatkan bahwa infeksi Trichuris trichiura lebih tinggi daripada Ascaris lumbricoides dengan prevalensi sebesar 42,1 \%. ${ }^{16}$ Penelitian yang dilakukan oleh Rahman di SDN 29 Purus Kecamatan Padang Barat Kota Padang menunjukkan hasil yang tidak sama, pada penelitian ini infeksi terbanyak disebabkan oleh Ascaris lumbricoides dengan prevalensi 43,1 \%. ${ }^{11}$ Hasil penelitian ini juga tidak sama pada penelitian yang dilakukan oleh Basalamah et al (2013) yang juga menunjukkan infeksi terbanyak disebabkan oleh Ascaris lumbricoides dengan prevalensi $33 \% .{ }^{17}$

Jumlah telur yang dihasilkan Ascaris lumbricoides mampu menghasilkan telur 200.000 butir/hari sedangkan Trichuris trichura 5.000 butir/hari, sehingga secara epidemiologi, penyebaran dari Ascaris lumbricoides lebih tinggi daripada Trichuris trichiura. Pada hasil penelitian ini menunjukkan infeksi yang disebabkan Trichuris trichiura lebih tinggi daripada Ascaris lumbricoides. Hal ini diduga disebabkan karena obat cacing yang bisa dibeli bebas mengandung pirantel palmoat, kemungkinan kecenderungan obat tersebut dikonsumsi masyarakat lebih tinggi, sehingga terjadi ketidakseimbangan transmisi pada Ascaris lumbricoides dan Trichuris trichiura. Sehingga transmisi infeksi yang disebabkan Ascaris lumbricoides lebih rendah daripada Trichuris trichiura.

Tingginya angka kejadian kecacingan ini disebabkan karena rata-rata siswa SDN 06 Pasir Jambak Kecamatan Koto Tangah Kota Padang bertempat tinggal di dekat pantai. Berdasarkan wawancara yang dilakukan pada guru dan beberapa orang siswa di SDN 06 Pasir Jambak Kecamatan Koto Tangah, masyarakat yang bertempat tinggal di sekitar pantai rata-rata tidak memiliki jamban di rumahnya sehingga mempunyai kebiasaan buang air besar di sepanjang pantai tersebut. Kebiasaan tidak mencuci tangan sebelum makan dan setelah buang air besar serta kebiasaan bermain ditanah tanpa memakai alas kaki juga berperan dalam penularan infeksi cacing ini. ${ }^{18}$

Penelitian ini menunjukkan terdapat 32 orang anak dengan kadar kolesterol normal (<200 mg/dl) dan 14 orang anak dengan kadar kolesterol tidak normal ( $\geq 200 \mathrm{mg} / \mathrm{dl}$ ). Kadar kolesterol total paling tinggi yaitu $271 \mathrm{mg} / \mathrm{dl}$ dan terendah yaitu $104 \mathrm{mg} / \mathrm{dl}$. Hasil 
penelitian ini menunjukkan bahwa terdapat perbedaan kadar kolesterol total yang bermakna antara anak terinfeksi dan tidak terinfeksi intestinal geohelminth $(p<0,05)$. Hasil penelitian ini sama dengan penelitian sebelumnya yang dilakukan oleh Oladele et al (2011) terhadap anak di Nigeria menunjukkan perbedaan kadar kolesterol total yang bermakna antara anak yang terinfeksi dan tidak terinfeksi intestinal geohelminth. Penelitian tersebut ditemukan penurunan konsentrasi kadar kolesterol total plasma dan High Density Lipoprotein (HDL) pada anak yang terinfeksi intestinal geohelminth. ${ }^{9}$ Hasil penelitian lain yang juga sama adalah penelitian yang dilakukan oleh Wiria et al (2015) terhadap individu dewasa berusia 18-80 tahun di Pulau Flores, Indonesia yang menunjukkan terdapat hubungan bermakna antara infeksi intestinal geohelminth dengan kadar kolesterol total darah. ${ }^{19}$

Hasil penelitian ini tidak sejalan dengan penelitian yang dilakukan oleh Yamamoto et al pada anak sekolah di Filipina yang menunjukkan bahwa tidak terdapat perbedaan kadar kolesterol yang bermakna pada anak yang terinfeksi dan tidak terinfeksi intestinal geohelminth $(P>0,05) .{ }^{20}$ Hal ini disebabkan pada penelitian tersebut tidak mengeksklusi anak yang memiliki IMT $\leq 16$, sehingga hasil penelitian tersebut memiliki rata-rata kolesterol pada kelompok terinfeksi dan tidak terinfeksi intestinal geohelminth yang lebih rendah daripada hasil penelitian ini.

Keterbatasan dalam penelitian ini adalah sulitnya mengatur waktu pengambilan tinja dan pemeriksaan tinja sehingga tinja diperiksa setelah lebih dari 1 hari. Pada penelitian ini juga tidak bisa melihat hubungan intensitas infeksi intestinal geohelminth dengan kadar kolesterol karena sampel yang positif terinfeksi intestinal geohelminth memiliki intensitas infeksi yang ringan.

\section{SIMPULAN}

Anak yang terinfeksi intestinal geohelminth memiliki kadar kolesterol total yang lebih rendah daripada anak yang tidak terinfeksi intestinal geohelminth.

\section{UCAPAN TERIMA KASIH}

Terima kasih kepada semua pihak atas bimbingan, bantuan, dan motivasi dalam penelitian ini serta semua responden yang telah memberikan kontribusi dalam pelaksanaan penelitian ini.

\section{DAFTAR PUSTAKA}

1. Safar R. Parasitologi kedokteran protozoologi, helmintologi dan entomologi. Edisi Khusus. Bandung: CV Yrama Widya; 2010.

2. World Health Organization (WHO). Soiltransmitted helminth infections. 2006 (diunduh 5 April 2016). Tersedia dari: http://www.who.int/ mediacentre/news/releases/20

06/pr60/en/index1.html

3. Darnely, Sungkar. Infeksi parasit usus pada anak panti asuhan di pondok gede Bekasi. J Indon Med Assoc. 2011;61(9):347 - 50.

4. Departemen Kesehatan RI PP-PL. Profil pengendalian penyakit dan penyehatan lingkungan tahun 2009. Jakarta: Depkes RI; 2009.

5. Dinas Kesehatan Kota Padang. Laporan Bulanan Data Kesehatan (LB.1). Padang: Dinas Kesehatan Kota Padang; 2014.

6. Samudar N, Hadju V, Jafar N. Hubungan infeksi kecacingan dengan status hemoglobin pada anak sekolah dasar di wilayah Pesisir Kota Makassar Propinsi Sulawesi Selatan [skripsi]. Makassar: Universitas Hasanuddin; 2013.

7. Doenhoff MJ, Stanley RG, Griffiths K, Jackson CL. An anti-atherogenic effect of Schistosoma mansoni infections in mice associated with a parasite-induced lowering of blood total cholesterol. United Kingdom. Cambridge University. 2002;125:415-21.

8. Stanley RG, Jackson CL, Griffiths K, Doenhoff MJ. Effects of Schistosoma mansoni worms and eggs on circulating cholesterol and liver lipids in mice. United Kingdom. Atherosclerosis. 2009: 207:131-8

9. Oladele HA, Jude OA, Japhet OM, Fatima SF, 
Nassar, Dienye A, et al. Plasma lipids and lipoproteins in selected primary school children infected with intestinal helminthiasis in a metropolitan area of Southwest Nigeria. Int J Biol Med Res. 2011; 2(4):933-37.

10. Murray RK, Granner DK, Rodwell WW. Biokimia Harper. Edisi ke-27. Alih bahasa: Pendit BU; alih editor bahasa indonesia: Wulandari $\mathrm{N}$ et al. Jakarta: EGC; 2009.

11. Rahman A. Hubungan infeksi cacing soil transmitted helminth (STH) dengan anemia [skripsi]. Padang: Universitas Andalas; 2015.

12. Handayani D, Ramdja M, Nurdianthi I. Hubungan infeksi Soil Transmitted Helminth (STH) dengan prestasi belajar pada siswa SDN 169 Kelurahan Gandus Kecamatan Gandus Kota Palembang. Majalah Kedokteran Universitas Sriwijaya. 2015;47(2).

13. Uneke C, Eze K, Oyibo P, Azu N, E Ali. Soiltransmitted helminth infection in school children in South-Eastern Nigeria: the public health implication. The Internet Journal of Third World Medicine. 2007;4(1):1-7.

14. Hotelz PJ, Bundy D, Beegle K, Brooker S, Drake L, Silva N, et al. Helminth Infections: soiltransmitted helminth infections and schistosomiasis. Dalam: Amison DT, Breman JG, Measham AR, et al, editor (penyunting). Disease Control Priorities in Developing Countries. Edisi ke-2. Washington: World Bank; 2006. hlm: 467-82.
15. Ginting A. Faktor-faktor yang berhubungan dengan kejadian kecacingan pada anak sekolah dasar di desa tertinggal Kecamatan Pangururan Kabupaten Samosir [skripsi]. Medan:Fakultas Kesehatan Masyarakat, Universitas Sumatera Utara; 2008.

16. Elmi, Sembiring T, Dewiyani B, Hamid E, Pasaribu S, Lubis C. Status gizi dan infestasi cacing usus pada anak sekolah dasar. Fakultas Kedokteran Bagian IImu Kesehatan Anak Universitas Sumatera Utara; 2004. e-USU Repository @ 2004.

17. Basalamah FM, Pateda V, Rampengan N. Hubungan infeksi Soil Transmitted Helminth dengan kadar hemoglobin anak sekolah dasar GMIM Buha Manado. Jurnal E-Clinic (ECL). 2014; 2(1).

18. Endriani, Mifbakhudin, Sayono. Beberapa faktor yang berhubungan dengan kejadian kecacingan pada anak usia 1-4 tahun. Universitas Muhammadiyyah Semarang. Jurnal Kesehatan Masyarakat Indonesia. 2011; 7(1): 22-35.

19. Wiria PE, Hamid F, Wammes LJ, Prasetyani MA, Dekkers OM, May L, et al. Infection with soiltransmitted helminths is associated with increased insulin sensitivity. PloS One. 2015; 10(6):1-11.

20. Yamamoto R, Nagai N, Kawabata M, Leon W, Ninomiya R, Koizumi N. Effect of intestinal helminthiasis on nutritional status of school children. Southeast Asian J Trop Med Public Health. 2000;31(4):755-61. 